\title{
Human apurinic/apyrimidinic endonuclease (APEI) is a prognostic factor in ovarian, gastro-oesophageal and pancreatico-biliary
}

\section{cancers}

\author{
A Al-Attar', L Gossage ${ }^{2}$, KR Fareed ${ }^{2}$, M Shehata', M Mohammed ${ }^{2}$, AM Zaitoun $^{3}$, I Soomro ${ }^{3}$, DN Lobo ${ }^{4}$, \\ R Abbotts ${ }^{2}$, S Chan' and S Madhusudan ${ }^{*, 2}$
}

'Department of Clinical Oncology, Nottingham University Hospitals NHS Trust, Nottingham, UK; ${ }^{2}$ Laboratory of Molecular Oncology, Academic Unit of Oncology, School of Molecular Medical Sciences, Faculty of Medicine and Health Sciences, University of Nottingham, Nottingham, UK; ${ }^{3}$ Department of Pathology, Nottingham University Hospitals NHS Trust, Nottingham, UK; ${ }^{4}$ Division of Gastrointestinal Surgery, Nottingham Digestive Diseases Centre, NIHR Biomedical Research Unit Nottingham University Hospitals NHS Trust, Queen's Medical Centre, Nottingham, UK

BACKGROUND: Altered DNA repair may be associated with aggressive tumour biology and impact upon response to chemotherapy and radiotherapy. We investigated whether expression of human AP endonuclease (APEI), a key multifunctional protein involved in DNA BER, would impact on clinicopathological outcomes in ovarian, gastro-oesophageal, and pancreatico-biliary cancer.

METHODS: Formalin-fixed human ovarian, gastro-oesophageal, and pancreatico-biliary cancers were constructed into TMAs. Expression of APEI was analysed by $I \mathrm{HC}$ and correlated to clinicopathological variables.

RESULTS: In ovarian cancer, nuclear APE I expression was seen in 71.9\% (97 out of 135) of tumours and correlated with tumour type $(P=0.006)$, optimal debulking $(P=0.009)$, and overall survival $(P=0.05)$. In gastro-oesophageal cancers previously exposed to neoadjuvant chemotherapy, 34.8\% (16 out of 46) of tumours were positive in the nucleus and this correlated with shorter overall survival $(P=0.005)$, whereas cytoplasmic localisation correlated with tumour dedifferentiation $(P=0.034)$. In pancreatico-biliary cancer, nuclear staining was seen in 44\% (32 out of 72) of tumours. Absence of cytoplasmic staining was associated with perineural invasion $(P=0.007)$, vascular invasion $(P=0.05)$, and poorly differentiated tumours $(P=0.068)$. A trend was noticed with advanced stage $(P=0.077)$.

CONCLUSIONS: Positive clinicopathological correlations of APEI expression suggest that APEI is a potential drug target in ovarian, gastro-oesophageal, and pancreatico-biliary cancers.

British Journal of Cancer (2010) I 02, 704-709. doi:10.1038/sj.bjc.660554I www.bjcancer.com

Published online 19 January 2010

(c) 2010 Cancer Research UK

Keywords: ovarian cancer; pancreatic adenocarcinoma; gastro-oesophageal cancer; immunohistochemistry; APE I

DNA base excision repair (BER) is involved in the repair of bases that have been damaged by alkylation, oxidation, or ringsaturation in addition to processing deaminated bases and DNA single-strand breaks. Although there is more than one subpathway of BER, in most cases excision of a damaged base by a DNA glycosylase enzyme leads to the formation of a potentially cytotoxic apurinic/apyrimidinic (AP) site intermediate (Hickson et al, 2000). This is a target for an AP endonuclease (APE1), which cleaves the phosphodiester backbone on the $5^{\prime}$ side of the AP site via a hydrolytic mechanism. The major AP endonuclease in human cells, APE1 (also called previously HAP1, Ref-1, and APEX1), accounts for over $95 \%$ of the total AP endonuclease activity in most cultured human cell lines (Demple et al, 1991; Robson and Hickson, 1991). In addition to its DNA-repair activity, APE1 also

*Correspondence: Dr S Madhusudan;

E-mail: srinivasan.madhusudan@nottingham.ac.uk

Received 29 October 2009; revised 9 December 2009; accepted 16

December 2009; published online 19 January 2010 regulates redox function (Robson and Hickson, 1991) and transcription (Bhakat et al, 2003; Fuchs et al, 2003).

Using either antisense oligonucleotides or siRNA approaches, several groups have reported that depletion of intracellular APE1 sensitises mammalian cells to a variety of DNA-damaging agents (Chen and Olkowski, 1994; Ono et al, 1994; Walker et al, 1994; Robertson et al, 1997; Evans et al, 2000; Silber et al, 2002). In pancreatic cancer cell lines for example, downregulation of APE1 potentiated the cytotoxicity of gemcitabine (Lau et al, 2004). APE1 downregulation has also been shown to block ovarian cancer cell growth (Fishel et al, 2008). In melanoma cell lines, APE1 downregulation led to increased apoptosis, whereas APE1 overexpression conferred protection from cisplatin- or $\mathrm{H}_{2} \mathrm{O}_{2}$ induced apoptosis. (Yang et al, 2005).

We have undertaken a drug discovery programme to isolate small-molecule inhibitors of APE1 (Madhusudan et al, 2005). In the previously published study, we provided the first preclinical evidence that APE1 inhibition by a small-molecule inhibitor potentiated the cytotoxicity of a panel of base-targeting agents thought to be repaired through BER (Madhusudan et al, 2005). To identify drug-like leads, we recently adopted an industry-standard, 
high-throughput, virtual screening strategy using first-generation inhibitors as templates and screened a chemical library of 2.6 million compounds. Several novel inhibitors of APE1 were identified with the ability to potentiate the cytoxicity of alkylating agents (unpublished data).

In the current study, we provide evidence that APE1 is a prognostic marker in ovarian, gastric, and pancreatico-biliary cancer. We demonstrate positive clinicopathological correlations of APE1 nuclear expression in ovarian, gastric, and pancreaticobiliary cancers, suggesting that APE1 is also a potential drug target in these tumours.

\section{MATERIALS AND METHODS}

\section{Study design and setting}

Expression of APE1 in ovarian cancer was investigated using a tissue microarray (TMA) of 157 ovarian cancer cases. Tissue was obtained from patients with primary ovarian cancer treated at Nottingham University Hospitals (NUH) between 2000 and 2007. Survival was calculated from the operation date until 1 April 2009 when any remaining survivors were censored. During the study period, patients were treated with either single agent carboplatin (65 patients $(41.4 \%)$ ) or platinum-based combination chemotherapy (89 patients (56.7\%): 79 out of 89 patients received carboplatin and paclitaxel; 4 out of 89 received cyclophosphamide/doxorubicin/cis-platinum (CAP); 3 out of 89 were treated in the ICON-5 trial using paclitaxel, carboplatin plus gemcitabine, or topotecan (Bookman et al, 2009); and 3 out of 89 were treated according to the SCOTROC trial protocol by carboplatin, docetaxel \pm topotecan; Kaye et al, 2009). Platinum resistance was defined as patients who had progression during first-line platinum chemotherapy or relapse within 6 months after treatment.

Expression of APE1 in gastro-oesophageal cancers was investigated using two TMA sets. The first set consisted of 142 gastric/ gastro-oesophageal cancer cases not exposed to neoadjuvant chemotherapy. With recent incorporation of neoadjuvant chemotherapy as a standard treatment option for operable gastro-oesophageal tumours (Cunningham et al, 2006), we also established a second TMA of 103 gastric/gastro-oesophageal cancer cases exposed to preoperative platinum-based chemotherapy. Tissue was obtained from patients treated at Nottingham University Hospitals (NUH) between 2001 and 2008. Survival was calculated from the date of diagnosis until 13 January 2009 when any remaining survivors were censored. During the study period, patients in the neoadjuvant arm with adenocarcinomas were treated with either neoadjuvant ECF (epirubicin $\left(50 \mathrm{mg} \mathrm{m}^{-2}\right.$ ), cisplatin $\left(60 \mathrm{mg} \mathrm{m}^{-2}\right)$, and continuous infusional 5-FU $\left(200 \mathrm{mg} \mathrm{m}^{-2}\right.$ per day)) or ECX (epirubicin $\left(50 \mathrm{mg} \mathrm{m}^{-2}\right)$, cisplatin $\left(60 \mathrm{mg} \mathrm{m}^{-2}\right)$, and capecetabine $\left(625 \mathrm{mg} \mathrm{m}^{-2}\right.$ p.o. b.d continuously)) chemotherapy up to three cycles prior to surgery. Patients with squamous cell carcinoma were treated with CF (cisplatin $\left(80 \mathrm{mg} \mathrm{m}^{-2}\right.$ ) and infusional 5-FU (1000 $\mathrm{mg} \mathrm{m}^{-2}$ daily for 4 days); Allum et al, 2009) chemotherapy up to two cycles prior to surgery.

Expression of APE1 in pancreatico-biliary cancer was investigated using a TMA of 120 cases. All the participants were patients who underwent pancreatic resection (for benign or malignant pancreatic disease) between June 2001 and June 2006 at NUH Queen's Medical Centre Campus. Cores from 72 malignant tumours were selected for analysis within this study, of which 34 had pancreatic adenocarcinoma (PAC), 20 had ampullary adenocarcinoma (AAC), and 18 had cholangiocarcinoma. Only 15 patients had received adjuvant 5-FU/folinic acid chemotherapy in this cohort.

The conduct of this study was approved by the Ethics Committee of Nottingham University Hospitals.

\section{Construction of TMA}

Tissue microarrays were constructed as described previously (Kononen et al, 1998). In short, area-specialised histopathologists identified and marked formalin-fixed, paraffin-embedded tissue blocks containing tumour tissue on haematoxylin- and eosinstained slides. The marked areas in these donor paraffin blocks were used to construct the TMA. Triplicate tissue cores with a diameter of $0.6 \mathrm{~mm}$ were taken from the marked areas and arrayed into a recipient paraffin block using a tissue puncher/arrayer (Beecher Instruments, Silver Spring, MD, USA) as previously described (Kononen et al, 1998). Five-micrometre sections of the tissue array block were cut and placed on Fisherbrand Colorfrost/ Plus microscope slides (Fisher Scientific, Pittsburgh, PA, USA) for immunohistochemical staining.

\section{Immunohistochemistry}

A standard streptavidin-biotin complex method was used. Negative controls were obtained by omitting the primary antibody in each case. The tissue slides were deparaffinised with xylene and then rehydrated through five decreasing concentrations of alcohol $(100,90,70,50$, and $30 \%)$ for $2 \mathrm{~min}$ each. Endogenous peroxidise activity was blocked by incubation in a $1 \%$ hydrogen peroxide/ methanol buffer. Antigen retrieval was performed by microwave treatment of the slides in sodium citrate buffer ( $\mathrm{pH}$ 6.0) for $10 \mathrm{~min}$. The slides were rinsed in phosphate buffer solution (PBS) and incubated with blocking serum diluted in PBS to block nonspecific staining. The slides were incubated for $1 \mathrm{~h}$ with the primary rabbit polyclonal anti-APE-1 antibody clone NB100-101 (Novus Biologicals Inc., Littleton, CO, USA) at a dilution of 1:500. After washing with PBS, sections were incubated with the secondary antibody (Vector Laboratories, Burlingame, CA, USA) for $30 \mathrm{~min}$ followed by the avidin-biotin complex for a further $30 \mathrm{~min}$. 3-3'-Diaminobenzidine tetrahydochloride was used as chromogen. All sections were counterstained with Gill's haematoxylin.

\section{Evaluation of immune staining}

The tumour cores were evaluated by specialist pathologists and oncologists blinded to the clinicopathological characteristics of patients. Whole-field inspection of the core was included in the assessment and intensities of staining were grouped as follows: $0=$ no staining; $1=$ weak staining; $2=$ moderate staining; and $3=$ strong staining. Cytoplasmic and nuclear staining were assessed separately for each core. Only stained malignant cells (epithelial cancer cells in ovarian cancer, ductal and acinar exocrine epithelial cells in pancreatico-billiary cancer) were included in the evaluation of staining. Stained stromal cells, inflammatory cells, and endocrine cells within islets of Langerhans were disregarded. Nuclear and cytoplasmic score were assigned separately for each core, and the mean of three cores was calculated for each sample. The results shown represent the mean score from the three cores available for each assessable patient sample. Not all cores within the TMA were suitable for immunohistochemistry (IHC) analyses due to small technical problems such that some cores were missing or lacked tumours.

\section{Statistical analysis}

Statistical analysis of data was performed using SPSS version 15.0 for Windows (SPSS Inc., Chicago, IL, USA). Univariate analysis of associations was determined using the Pearson $\chi^{2}$-test. Survival rates were calculated from the time of resection until the end of the follow-up period and Kaplan-Meier curves were plotted. The statistical significance of differences between survival rates was determined using the log-rank test. Survival was censored if 
the patient was still alive or died of other causes. $P$-values $<0.05$ were identified as statistically significant. The threshold for significance was adjusted to $<0.01$ for subset analyses.

\section{RESULTS}

\section{Patient demographics}

Ovarian cancer This cohort comprised female patients with a median age of 61 years (range 33-87, mean 60 years) (Table 1a). Out of the 157 patients included in the study, $54(34 \%)$ were dead before the end of the follow-up period. Histologically, most patients were found to have a serous cystadenocarcinoma (56\%), followed by endometrioid (21\%), clear-cell carcinoma (13\%), mucinous cystadenocarcinoma (8\%), or other types (2\%). Tumours displayed poor histological differentiation in $73 \%$ of cases. The majority of tumours were classified as FIGO stage III $(45 \%)$.

Gastro-oesophageal cancer There were two groups of patients: those who received at least one cycle of neoadjuvant chemotherapy (neoadjuvant group) and those who underwent primary surgery (primary group) (Table 1b). There were 103 patients in the neoadjuvant group, with a median age of 63 years and $81 \%$ were male. T3 tumours were the majority, constituting $62 \%$ of cases.

Table Ia Patient demographics and pathological features for Ovarian cancer

\begin{tabular}{|c|c|c|}
\hline Characteristics & Frequencies & Percentages (\%) \\
\hline \multicolumn{3}{|l|}{ Pathology } \\
\hline Serous cystadenocarcinoma & 88 & 56 \\
\hline Endometrioid & 33 & 21 \\
\hline Clear cell carcinoma & 21 & 13 \\
\hline Mucinous cystadenocarcinoma & 12 & 8 \\
\hline Other & 3 & 2 \\
\hline \multicolumn{3}{|l|}{ Grade } \\
\hline I & 20 & 13 \\
\hline 2 & 23 & 14 \\
\hline 3 & 114 & 73 \\
\hline \multicolumn{3}{|l|}{ Residual tumour } \\
\hline None & 88 & 56 \\
\hline Present & 69 & 44 \\
\hline \multicolumn{3}{|l|}{ Stage } \\
\hline IC & 44 & 28 \\
\hline ॥ & 21 & 13 \\
\hline III & 71 & 45 \\
\hline IV & 21 & 14 \\
\hline \multicolumn{3}{|l|}{ Chemotherapy } \\
\hline Carboplatin monotherapy & 65 & 41 \\
\hline Carboplatin combination therapy & 89 & 57 \\
\hline No chemotherapy & 3 & 2 \\
\hline \multicolumn{3}{|l|}{ Platinum sensitivity } \\
\hline Sensitive & 104 & 66 \\
\hline Resistant & 50 & 32 \\
\hline Unknown & 3 & 2 \\
\hline \multicolumn{3}{|l|}{ Relapse status } \\
\hline Relapsed & 75 & 48 \\
\hline Relapse-free & 75 & 48 \\
\hline Unknown & 7 & 4 \\
\hline \multicolumn{3}{|l|}{ Survival status } \\
\hline Living & 103 & 66 \\
\hline Dead & 54 & 34 \\
\hline
\end{tabular}

Table Ib Patient demographics and pathological features for Gastrooesophageal cancer

\begin{tabular}{|c|c|c|c|c|}
\hline Characteristics & $\begin{array}{l}\text { Primary } \\
\text { surgery } \\
\text { arm (n) }\end{array}$ & $\begin{array}{c}\text { Percentage } \\
\text { (\%) }\end{array}$ & $\begin{array}{l}\text { Neoadjuvant } \\
\operatorname{arm}(n)\end{array}$ & $\begin{array}{c}\text { Percentage } \\
\text { (\%) }\end{array}$ \\
\hline Patients (n) & & 142 & 10 & \\
\hline Median age & & 74 & 6. & \\
\hline \multicolumn{5}{|l|}{ Sex } \\
\hline Male & 105 & $73.9 \%$ & 83 & $81 \%$ \\
\hline Female & 37 & $26 \%$ & 20 & $19 \%$ \\
\hline \multicolumn{5}{|l|}{ T stage } \\
\hline TI & 14 & $9.8 \%$ & 4 & $3.8 \%$ \\
\hline $\mathrm{T} 2$ & 48 & $33.8 \%$ & 24 & $23.6 \%$ \\
\hline T3 & 75 & 52.8 & 64 & $62 \%$ \\
\hline $\mathrm{T} 4$ & 5 & $3.5 \%$ & 9 & $8.6 \%$ \\
\hline $\mathrm{TX}$ & & & 2 & $2 \%$ \\
\hline \multicolumn{5}{|l|}{$N$ stage } \\
\hline No & 33 & $23.2 \%$ & 29 & $28 \%$ \\
\hline$\geqslant \mathrm{NI}$ & 109 & $76.8 \%$ & 74 & $72 \%$ \\
\hline \multicolumn{5}{|l|}{ M stage } \\
\hline $\mathrm{MO}$ & 140 & $98.5 \%$ & 103 & $100 \%$ \\
\hline $\mathrm{MI}$ & 2 & $1.4 \%$ & - & \\
\hline \multicolumn{5}{|l|}{ Vascular invasion } \\
\hline No & 44 & $40 \%$ & 57 & $55 \%$ \\
\hline Yes & 98 & $60 \%$ & 46 & $45 \%$ \\
\hline \multicolumn{5}{|l|}{ Perineural invasion } \\
\hline No & 66 & $46 \%$ & 15 & $15 \%$ \\
\hline Yes & 76 & $54 \%$ & 88 & $85 \%$ \\
\hline \multicolumn{5}{|l|}{ Status } \\
\hline Alive & 54 & $38 \%$ & 47 & $46 \%$ \\
\hline Dead & 87 & $62 \%$ & 56 & $54 \%$ \\
\hline
\end{tabular}

A total of 142 cases were in the primary group, with a median age of 74 years: $74 \%$ were male, $53 \%$ had T3 tumours.

Pancreatico-biliary cancer Of the 72 patients with pancreaticobilairy tumours, 44 patients were male and 28 were female (Table 1c). Thirty-four had PAC, 20 had AAC, and 18 had cholangiocarcinoma. The median follow-up time was 20.4 months; 35 patients $(38 \%)$ died of their cancer at the time of the observation period, while only 12 patients $(13 \%)$ were still alive at 5 years following the operation. The median survival was 37.8 months.

\section{APE1 expression and clinicopathological correlations}

Ovarian cancer Apyrimidinic endonuclease-1 expression was noted both in the cytoplasmic and nuclear compartments in ovarian cancer; however, nuclear staining was more prevalent (Table 2). Of the 135 evaluable cores, 97 had nuclear expression (71.9\%), but only 40 had cytoplasmic expression (29.6\%). It was seen more often localised to the nucleus only (45.9\%) (Figure 1A) as compared with $3.7 \%$ showing exclusively cytoplasmic staining. There was a significant difference in the level of APE1 expression among the different histological subtypes of ovarian cancer, with serous and mucinous tumours displaying nuclear APE1 more frequently than endometrioid and clear-cell carcinomas $(P=0.006)$ (Table 3$)$. Nuclear localisation of APE1 correlated with a lower likelihood of achieving optimal debulking after initial surgery $(P=0.009)$, suggesting a more aggressive phenotype. This was also reflected on survival; APE1-positive cases had worse 
Table Ic Patient demographics and pathological features for Pancreatico-biliary cancer

\begin{tabular}{|c|c|c|}
\hline Characteristics & $\begin{array}{c}\text { No of } \\
\text { patients }\end{array}$ & $\begin{array}{c}\% \text { of total } \\
\text { number of } \\
\text { recorded cases }\end{array}$ \\
\hline \multicolumn{3}{|l|}{ Age (years) } \\
\hline$<40$ & 0 & \\
\hline $41-60$ & 28 & 38.9 \\
\hline$>60$ & 44 & 61.1 \\
\hline \multicolumn{3}{|l|}{ Sex } \\
\hline Male & 44 & 61.1 \\
\hline Female & 28 & 38.9 \\
\hline \multicolumn{3}{|l|}{ Grade } \\
\hline Poor & 14 & 19.4 \\
\hline Well/moderate & 49 & 68.1 \\
\hline Unknown & 9 & 12.5 \\
\hline \multicolumn{3}{|l|}{ Lymph node status } \\
\hline Not involved & 17 & 23.6 \\
\hline Involved & 46 & 63.9 \\
\hline Unknown & 9 & 12.5 \\
\hline \multicolumn{3}{|l|}{ Vascular invasion } \\
\hline Negative & 33 & 45.8 \\
\hline Positive & 37 & 51.4 \\
\hline Unknown & 2 & 2.8 \\
\hline \multicolumn{3}{|l|}{ Perineural invasion } \\
\hline Negative & 32 & 44.4 \\
\hline Positive & 39 & 54.2 \\
\hline Unknown & I & 1.4 \\
\hline \multicolumn{3}{|l|}{ T stage } \\
\hline 0 & I & 1.4 \\
\hline I & 7 & 9.7 \\
\hline 2 & 20 & 27.8 \\
\hline 3 & 40 & 55.6 \\
\hline 4 & 3 & 4.2 \\
\hline Unknown & I & 1.4 \\
\hline \multicolumn{3}{|l|}{ Outcome } \\
\hline Alive & 26 & 36.1 \\
\hline Died of disease & 30 & 41.7 \\
\hline Died of other cause & 16 & 22.2 \\
\hline \multicolumn{3}{|l|}{ Site } \\
\hline Pancreatic & 24 & 38.7 \\
\hline Ampullary & 20 & 32.3 \\
\hline Cholangio & 18 & 29 \\
\hline
\end{tabular}

Table 2 The distribution of nuclear APEI expression in ovarian, pancreatico biliary, and gastric cancers (primary and neoadjuvant series)

\begin{tabular}{lcccc}
\hline & Ovarian & Pancreatic & $\begin{array}{c}\text { Gastric } \\
\text { (primary) }\end{array}$ & $\begin{array}{c}\text { Gastric } \\
\text { (neo-adjuvant) }\end{array}$ \\
\hline Positive & $97(71.9 \%)$ & $32(44.4 \%)$ & $41(44.1 \%)$ & $16(34.8)$ \\
Negative & $38(28.1 \%)$ & $40(55.6 \%)$ & $52(55.9 \%)$ & $30(65.2 \%)$ \\
Total & $135(100 \%)$ & $72(100 \%)$ & $93(100 \%)$ & $46(100 \%)$ \\
\hline
\end{tabular}

overall survival (median survival time $=52$ months) as compared with 71 months for APE1-negative patients. This difference was statistically significant as shown in the Kaplan-Meier graph and log-rank test $(P=0.05)$ (Figure $2 \mathrm{~A})$. No significant correlations were seen between APE1 and FIGO stage or with histological grade.

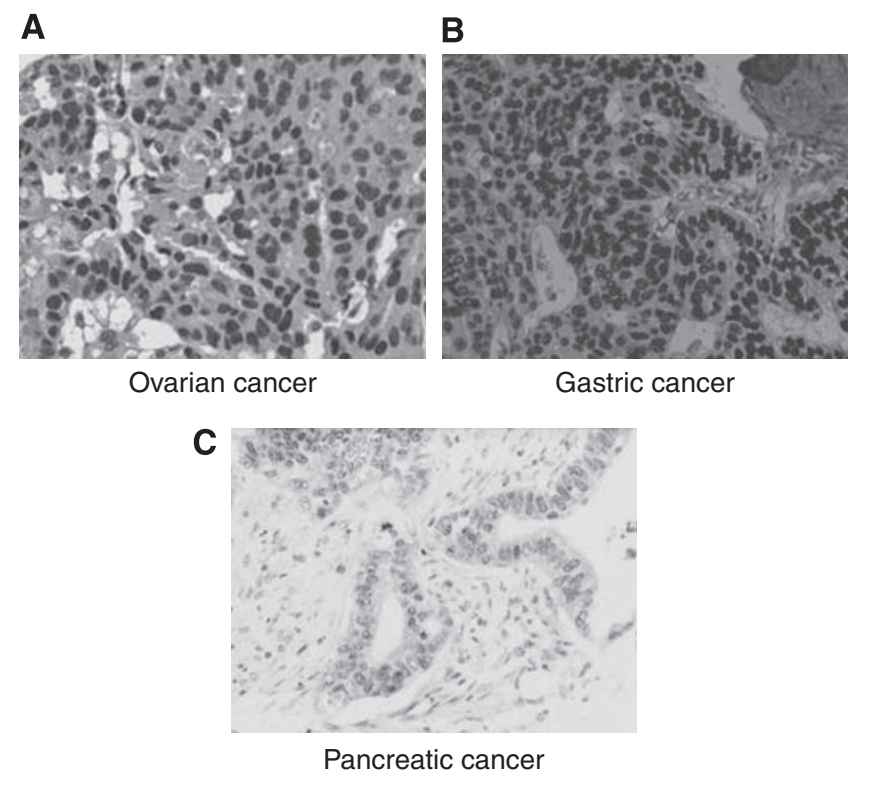

Figure I Microphotographs of ovarian cancer $(\mathbf{A})$, gastric cancer $(\mathbf{B})$, and PAC $(\mathbf{C})$ showing positive nuclear APEI expression (magnification $\times 200)$.

Table 3 Cross-tabulation of APEI expression in ovarian cancer with histopathological subtypes

\begin{tabular}{|c|c|c|c|c|c|c|}
\hline \multicolumn{7}{|c|}{$\begin{array}{l}\text { APEI nuclear ovarian cancer pathological subtypes - Cross-tabulation } \\
\text { Pathological subtypes }\end{array}$} \\
\hline & Serous & Mucinous & Endometroid & $\begin{array}{c}\text { Clear } \\
\text { cell }\end{array}$ & Other & Total \\
\hline \multicolumn{7}{|l|}{ APE I nuclear } \\
\hline \multicolumn{7}{|l|}{ Negative } \\
\hline $\begin{array}{l}\text { Count } \\
\%\end{array}$ & $\begin{array}{c}14 \\
17.9 \%\end{array}$ & $\begin{array}{c}3 \\
30.0 \%\end{array}$ & $\begin{array}{c}12 \\
42.9 \%\end{array}$ & $\begin{array}{c}9 \\
52.9 \%\end{array}$ & $\begin{array}{c}0 \\
0 \%\end{array}$ & $\begin{array}{c}38 \\
28.1 \%\end{array}$ \\
\hline \multicolumn{7}{|l|}{ Positive } \\
\hline $\begin{array}{l}\text { Count } \\
\%\end{array}$ & $\begin{array}{c}64 \\
82.1 \%\end{array}$ & $\begin{array}{c}7 \\
70.0 \%\end{array}$ & $\begin{array}{c}16 \\
57.1 \%\end{array}$ & $\begin{array}{c}8 \\
47.1 \%\end{array}$ & $\begin{array}{c}2 \\
100.0 \%\end{array}$ & $\begin{array}{c}97 \\
71.9 \%\end{array}$ \\
\hline \multicolumn{7}{|l|}{ Total } \\
\hline $\begin{array}{l}\text { Count } \\
\%\end{array}$ & $\begin{array}{c}78 \\
100 \%\end{array}$ & $\begin{array}{c}10 \\
100 \%\end{array}$ & $\begin{array}{c}28 \\
100 \%\end{array}$ & $\begin{array}{c}17 \\
100 \%\end{array}$ & $\begin{array}{c}2 \\
100 \%\end{array}$ & $\begin{array}{c}135 \\
100 \%\end{array}$ \\
\hline
\end{tabular}

Abbreviation: $\mathrm{APEI}=$ apurinic/apyrimidinic endonuclease- I. A strong correlation was found $(P=0.006)$.

Platinum resistance (defined as patients who had progression during first-line platinum chemotherapy or relapse within 6 months after treatment) was more frequently seen in APE1positive cases $(35.8 \%)$ as compared with APE1-negative patients $(21.1 \%)$; however, this did not reach statistical significance $(P=0.09)$.

Gastro-oesophageal cancer In the primary-group TMAs, 41 out of 93 tumours that were stained for APE1 showed specific nuclear staining $(44.1 \%)$ and 48 out of $93(51.6 \%)$ were positive in the cytoplasm compartment as well (Table 2). In the neoadjuvantgroup TMAs, 16 out of 46 tumours that were stained for APE1 showed specific nuclear staining (34.8\%) (Figure 1B) and 32 out of $46(69.6 \%)$ were positive in the cytoplasm. In the neoadjuvant group, nuclear APE1 correlated with worse overall survival in 
A

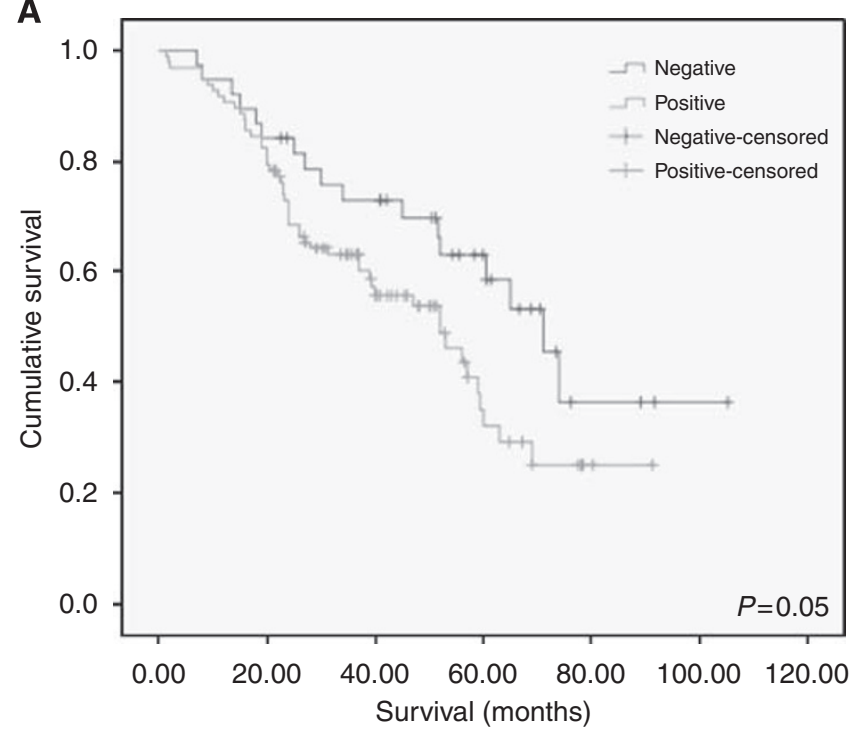

B

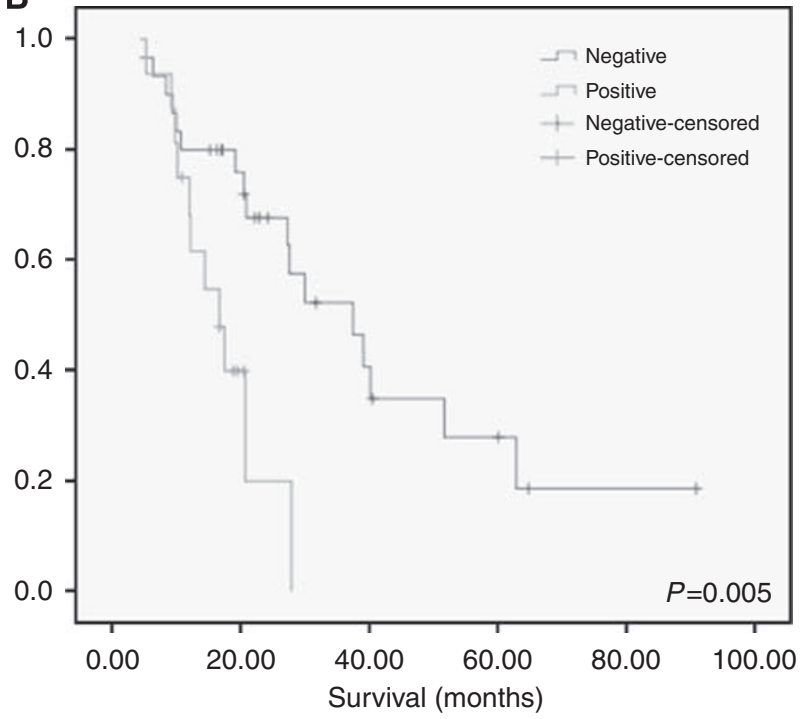

Figure 2 Kaplan-Meier curves showing overall survival in ovarian (A) and gastric (B) cancers according to the expression of APEI. In both cases, APEI was associated with worse survival (log-rank test $P$-value $=0.05$ and 0.005 for ovarian and gastric cancers, respectively)

patients receiving platinum-based neoadjuvant chemotherapy $(P=0.005)$ (Figure 2B). Cytoplasmic APE1 correlated with tumour differentiation $(P=0.034)$. No significant correlations were seen in the primary surgery group.

Pancreatico-biliary cancer The number of cancer tissue cores suitable for immunohistochemical analyses was 72, which comprised PAC $(n=34)$ and AAC $(n=20)$, and cholangiocarcinoma $(n=18)$ (Table 2). Overall, cytoplasmic expression of APE1 was never seen in the absence of nuclear expression in either tumour or normal tissues. Nuclear staining only was seen in $44 \%$ of all periampullary tumours (32 out of 72 ) (Figure 1C), 35\% (12 out of 34 ) of PACs, $60 \%$ (12 out of 20 ) of AACs, and $44 \%$ ( 8 out of 18) of cholangiocarcinomas. Absence of cytoplasmic staining was associated with vascular invasion $(P=0.05)$, perineural invasion $(P=0.007)$, and a trend towards advanced stage $(P=0.077)$ and poor differentiation (grade- 3 poorly differentiated adenocarcinoma) $(P=0.068)$.

\section{DISCUSSION}

Overall prognosis of advanced melanoma, ovarian, gastro-oesophageal, and pancreatico-biliary cancer remains poor. New treatment strategies are urgently required to address this largely unmet need. Cytotoxic agents (such as alkylating agents and platinum compounds) and ionising radiation used in the treatment of these tumours induce DNA damage (such as base damage and others) in cells. Cancer cells proficient in DNA repair are able to repair such DNA damage and continue to survive. This is a significant cause for therapeutic resistance and impacts negatively on patient outcomes. Pharmacological inhibition of DNA repair is likely to enhance the cytotoxicity in cancer cells and improve tumour response in patients. APE1 is a key multifunctional protein essential for DNA BER, in addition to redox regulation of transcription factors and transcriptional regulation. It is widely accepted that nuclear expression of APE1 is involved in DNA repair, whereas cytoplasmic expression may be involved in redox/ transcriptional regulation.

In the current study we have demonstrated the potential APE1 expression has as a negative prognostic factor in cancer patients.
Nuclear expression of APE1 was frequently seen in ovarian, gastrooesophageal, and pancreatico-biliary cancers. In ovarian cancer, nuclear APE1 expression was seen commonly in serous and mucinous tumours $(P=0.006)$. In addition, sub-optimal debulking and residual tumour was seen more frequently in tumours with nuclear expression of APE1, implying aggressive tumour biology $(P=0.009)$. In fact, this was reflected in poor overall survival in patients $(P=0.05)$. Interestingly, we also found evidence that APE1 expression may predict platinum resistance in patients, although this did not reach statistical significance $(P=0.09)$. The negative prognostic impact was also seen in gastro-oesophageal cancer where patients who received neoadjuvant platinum-based chemotherapy and whose tumours showed APE1 nuclear expression did significantly worse as compared with non-expressors $(P=0.005)$. Our study is consistent with recent preclinical observations using melanoma cell lines where APE1 overexpression conferred protection from cisplatin (Yang et al, 2005). Moreover, in lung cancer, blocking APE1 function potentiated cisplatin cytotoxicity (Wang et al, 2009). These studies imply that APE1 is involved in the repair of damage induced by platinating agents, and current evidence suggests that the protective effect may be contributed by the DNA repair as well as the redoxregulatory activity of APE1. The negative prognostic significance of APE1 has also been recently demonstrated in osteosarcoma (Wang et al, 2004) and head and neck cancer (Koukourakis et al, 2001).

Apyrimidinic endonuclease-1 exhibits complex and heterogeneous staining patterns. Although the biological relevance of the compartmentalisation of APE1 is not understood, its complexity suggests that APE1 localisation in cells is tightly regulated. In addition, as the nuclear expression of APE1 is involved in DNA repair and the cytoplasmic expression may be involved in redox/ transcriptional regulation, it is speculated that the compartmentalistion may reflect distinct functions of APE1 in cells. The altered subcellular localisation of APE1 in pancreatico-biliary cancers observed in our study is distinct to observations in other tumours. Nuclear staining only was seen in $44 \%$ of all periampullary tumours. Combined nuclear and cytoplasmic expression was seen in $25 \%$ of tumours. Cytoplasmic expression of APE1 was never seen in the absence of nuclear expression. Absence of cytoplasmic expression correlated to adverse prognostic features. This is in contrast to tumours such as breast cancer. In normal breast tissue, 
APE1 localisation is predominantly nuclear, whereas in breast carcinomas, nuclear, cytoplasmic, and nuclear/cytoplasmic stainings were observed (Kakolyris et al, 1998; Puglisi et al, 2002). Furthermore, while nuclear localisation was associated with good prognostic features (being related to better differentiation, low angiogenesis, and negative lymph node status), cytoplasmic and combined nuclear/cytoplasmic localisation were associated with poor prognostic factors, such as angiogenesis together with node and p53 positivity (Kakolyris et al, 1998; Puglisi et al, 2002). A dysregulation in nuclear $v s$ cytoplasmic ratio towards increased cytoplasmic staining was also observed in thyroid carcinomas (Tell et al, 2000) and prostate cancer (Kelley et al, 2001).

In conclusion, we have shown prognostic implications of APE1 in ovarian, gastro-oesophageal, and pancreatico-biliary cancer. Moreover our study suggests that APE1 is a potential drug target in these tumours. The recent evidence of BER modulation using PARP inhibitors that have shown promise in recent clinical trials in ovarian and breast cancer (Lord and Ashworth, 2008), implies that APE1 inhibitors may have similar clinical application in patients.

\section{REFERENCES}

Allum WH, Stenning SP, Bancewicz J, Clark PI, Langley RE (2009) Longterm results of a randomized trial of surgery with or without preoperative chemotherapy in esophageal cancer. J Clin Oncol 27: $5062-5067$

Bhakat KK, Izumi T, Yang SH, Hazra TK, Mitra S (2003) Role of acetylated human AP-endonuclease (APE1/Ref-1) in regulation of the parathyroid hormone gene. $E M B O J$ 22: 6299-6309

Bookman MA, Brady MF, McGuire WP, Harper PG, Alberts DS, Friedlander M, Colombo N, Fowler JM, Argenta PA, De Geest K, Mutch DG, Burger RA, Swart AM, Trimble EL, Accario-Winslow C, Roth LM (2009) Evaluation of new platinum-based treatment regimens in advanced-stage ovarian cancer: a Phase III Trial of the Gynecologic Cancer Intergroup. J Clin Oncol 27: 1419-1425

Chen DS, Olkowski ZL (1994) Biological responses of human apurinic endonuclease to radiation-induced DNA damage. Ann NY Acad Sci 726: $306-308$

Cunningham D, Allum WH, Stenning SP, Thompson JN, Van de Velde CJ, Nicolson M, Scarffe JH, Lofts FJ, Falk SJ, Iveson TJ, Smith DB, Langley RE, Verma M, Weeden S, Chua YJ, Participants MT (2006) Perioperative chemotherapy $v s$ surgery alone for resectable gastroesophageal cancer. N Engl J Med 355: 11-20

Demple B, Herman T, Chen DS (1991) Cloning and expression of APE, the cDNA encoding the major human apurinic endonuclease: definition of a family of DNA repair enzymes. Proc Natl Acad Sci USA 88: 11450-11454

Evans AR, Limp-Foster M, Kelley MR (2000) Going APE over ref-1. Mutat Res 461: $83-108$

Fishel ML, He Y, Reed AM, Chin-Sinex H, Hutchins GD, Mendonca MS, Kelley MR (2008) Knockdown of the DNA repair and redox signaling protein Ape1/Ref-1 blocks ovarian cancer cell and tumor growth. DNA Rep 7: $177-186$

Fuchs S, Philippe J, Corvol P, Pinet F (2003) Implication of Ref-1 in the repression of renin gene transcription by intracellular calcium. J Hypertens 21: $327-335$

Hickson ID, Gorman MA, Freemont PS (2000) Structure and Functions of the Major Human AP Endonuclease HAP1/Ref-1, 1st edn. Humana Press Inc.: Totowa, $\mathrm{NJ}$

Kakolyris S, Kaklamanis L, Engels K, Fox SB, Taylor M, Hickson ID, Gatter KC, Harris AL (1998) Human AP endonuclease 1 (HAP1) protein expression in breast cancer correlates with lymph node status and angiogenesis. Br J Cancer 77: 1169-1173

Kaye SB, Vasey P, Rustin G, Pledge S, Williams C, Gabra H, Skailes G, Lamont A, Lewsley L, Paul J, Scottish Gynaecological Cancer Trials G (2009) Randomized trial of intrapatient dose escalation of single agent carboplatin as first-line treatment for advanced ovarian cancer: an SGCTG study (SCOTROC 4). J Clin Oncol (Meeting Abstracts) 27: $5537-5538$

Kelley MR, Cheng L, Foster R, Tritt R, Jiang J, Broshears J, Koch M (2001) Elevated and altered expression of the multifunctional DNA base excision repair and redox enzyme Ape1/ref-1 in prostate cancer. Clin Cancer Res 7: 824-830

Kononen J, Bubendorf L, Kallioniemi A, Barlund M, Schraml P, Leighton S, Torhorst J, Mihatsch MJ, Sauter G, Kallioniemi OP (1998) Tissue microarrays for high-throughput molecular profiling of tumor specimens. Nat Med 4: 844-847
Koukourakis MI, Giatromanolaki A, Kakolyris S, Sivridis E, Georgoulias V, Funtzilas G, Hickson ID, Gatter KC, Harris AL (2001) Nuclear expression of human apurinic/apyrimidinic endonuclease (HAP1/Ref-1) in headand-neck cancer is associated with resistance to chemoradiotherapy and poor outcome. Int J Radiat Oncol Biol Phys 50: 27-36

Lau JP, Weatherdon KL, Skalski V, Hedley DW (2004) Effects of gemcitabine on APE/ref-1 endonuclease activity in pancreatic cancer cells, and the therapeutic potential of antisense oligonucleotides. $\mathrm{Br} \mathrm{J}$ Cancer 91: 1166-1173

Lord CJ, Ashworth A (2008) Targeted therapy for cancer using PARP inhibitors. Curr Opin Pharmacol 8: 363-369

Madhusudan S, Smart F, Shrimpton P, Parsons JL, Gardiner L, Houlbrook S, Talbot DC, Hammonds T, Freemont PA, Sternberg MJ, Dianov GL, Hickson ID (2005) Isolation of a small molecule inhibitor of DNA base excision repair. Nucleic Acids Res 33: 4711-4724

Ono Y, Furuta T, Ohmoto T, Akiyama K, Seki S (1994) Stable expression in rat glioma cells of sense and antisense nucleic acids to a human multifunctional DNA repair enzyme, APEX nuclease. Mutat Res 315: 55-63

Puglisi F, Barbone F, Tell G, Aprile G, Pertoldi B, Raiti C, Kelley MR, Damante G, Sobrero A, Beltrami CA, Di Loreto C (2002) Prognostic role of Ape/Ref-1 subcellular expression in stage I-III breast carcinomas. Oncol Rep 9: $11-17$

Robertson KA, Hill DP, Xu Y, Liu L, Van Epps S, Hockenbery DM, Park JR, Wilson TM, Kelley MR (1997) Downregulation of apurinic/ apyrimidinic endonuclease expression is associated with the induction of apoptosis in differentiating myeloid leukemia cells. Cell Growth Differ 8: $443-449$

Robson CN, Hickson ID (1991) Isolation of cDNA clones encoding a human apurinic/apyrimidinic endonuclease that corrects DNA repair and mutagenesis defects in E. coli xth (exonuclease III) mutants. Nucleic Acids Res 19: $5519-5523$

Silber JR, Bobola MS, Blank A, Schoeler KD, Haroldson PD, Huynh MB, Kolstoe DD (2002) The apurinic/apyrimidinic endonuclease activity of Ape1/Ref-1 contributes to human glioma cell resistance to alkylating agents and is elevated by oxidative stress. Clin Cancer Res 8: 3008-3018

Tell G, Pellizzari L, Pucillo C, Puglisi F, Cesselli D, Kelley MR, Di Loreto C, Damante G (2000) TSH controls Ref-1 nuclear translocation in thyroid cells. J Mol Endocrinol 24: 383-390

Walker LJ, Craig RB, Harris AL, Hickson ID (1994) A role for the human DNA repair enzyme HAP1 in cellular protection against DNA damaging agents and hypoxic stress. Nucleic Acids Res 22: 4884-4889

Wang D, Luo M, Kelley MR (2004) Human apurinic endonuclease 1 (APE1) expression and prognostic significance in osteosarcoma: enhanced sensitivity of osteosarcoma to DNA damaging agents using silencing RNA APE1 expression inhibition. Mol Cancer Ther 3: 679-686

Wang D, Xiang DB, Yang XQ, Chen LS, Li MX, Zhong ZY, Zhang YS (2009) APE1 overexpression is associated with cisplatin resistance in non-small cell lung cancer and targeted inhibition of APE1 enhances the activity of cisplatin in A549 cells. Lung Cancer 66: 298 - 304

Yang S, Irani K, Heffron SE, Jurnak F, Meyskens Jr FL (2005) Alterations in the expression of the apurinic/apyrimidinic endonuclease-1/redox factor-1 (APE/Ref-1) in human melanoma and identification of the therapeutic potential of resveratrol as an APE/Ref-1 inhibitor. Mol Cancer Ther 4: $1923-1935$ 